\title{
DIVERSITY OF SEED BORNE FUNGI ASSOCIATED WITH FOURTEEN VARIETIES OF STORAGE COTTON (Gossypium hirsutum L.) SEEDS
}

\author{
Khatun, A., S. Shamsi and M. A. Bashar \\ Mycology and Plant Pathology Laboratory, Department of Botany, University of Dhaka, Dhaka- 1000, \\ Bangladesh
}

\begin{abstract}
Present paper deals with the occurrence and diversity of fungi on storage cotton (Gossypium hirsutum L.) seeds. 24 species of the fungi were found associated with the seeds of 14 varieties of cotton after 10 months of storage. The isolated fungi were Aspergillus flavus Link, A. fumigatus Fresenius, A. niger (Type 1 and Type 2) Van Tiegh, A. ochraceus K. Wilhelm, A. nidulans Eidam, Aspergillus sp.1, Aspergillus sp.2, Aspergillus sp.3, Curvularia lunata (Wakker) Boedijn, Colletotrichum gloeosporioides Penz \& Sacc, C. gossypii Southw., Chaetomium globosum Kunze., Fusarium nivale (Fr.) Sorauer, F. moniliforme J. Shelden, F. oxysporum Schlechtendal, F. fujikuroi Nirenberg, Mucor sp. P. Micheli ex L., Penicillium sp.1 and sp.2 Link, Rhizoctonia solani Khun., Rhizopus stolonifer (Ehrenb.) Vuill., Rhizomucor Lucet \& Costantin, Syncephalastrum racemosum Cohn and Trichoderma viride Pers. The association of fungi with cotton seeds was recorded within two months of harvest, after 6 and 10 months of storage. The association of fungi varied with duration of storage periods. Aspergillus flavus, A. fumigatus, A. niger, Chaetomium globosum, Penicillium sp.1 and Rhizopus stolonifer were found in all the examined varieties. These were the most predominant fungi in terms of prevalence with the increase of storage periods. The fungal association with the seeds of cotton also affected the germination, seedling mortality, height and vigor. The total association of fungi in cotton seeds was the highest in cotton variety CB10 (204) and the lowest in CB8 (71). On the other hand, the total fungal association of Rhizopus stolonifer was the highest (337) and Colletotrichum gossypii was the lowest (1).
\end{abstract}

Key words: Biodiversity, cotton seeds, fungi, germination, seedling height, seedling mortality, vigor index.

\section{INTRODUCTION}

Cotton is one of the most known and reliable fiber yielding as well as cash crops around the world. Its seeds are also used in oil production. It is harvested as seed cotton and ginned to separate seed and lint (Tripathi et al. 2014). Cotton is cultivated in more than seventy countries, which represents $2.5 \%$ of all cultivated land and grows mostly in the tropical and subtropical regions of the world. Pathogen free healthy seeds are prerequisites for healthy and high yield crop production of all agricultural products. The lack of high quality seeds and the prevalence of seed borne organisms are the main constraints of crop production.

Fungi are the largest group of the seed-borne pathogens due to their capacity of multiplication and survival in nature (Neergaard 1977, Richardson 1990, Machado and Langerak 2002). Cotton is generally propagated by seeds and these are potential harbor of numerous micro-fungi which may impair seed germination resulting in the production of abnormal seedlings. Most cotton diseases are transmitted through seeds which in most cases affect the quality of the fibre and seed. The seed borne pathogens may cause discoloration of seed and embryos, seed rot, seed necrosis, reduce germination and seedling damage (Khanzada et al. 2002, Jeyalakshmi et al. 1999, Eisa et al. 2007, Tomar et al. 2012). Cotton seeds in storage carry 'field' and 'storage' fungi. Most of the storage pathogens are Penicillium, Aspergillus and Rhizopus.

Lot of research has been done in home and abroad on cotton diseases and their control but information on storage seed borne mycoflora of cotton seeds is inadequate. Considering the importance of this crop present research work was undertaken to study the diversity of fungi in different varieties of cotton seeds in storage condition. 


\section{MATERIALS AND METHODS}

An investigation was conducted on the storage seeds of cotton. The seeds of fourteen varieties of cotton (CB 1 - CB 14) were collected from Cotton Research, Training and Seed multiplication Farm, Sreepur, Gazipur. Samples were collected after harvesting and kept in clean glass jar, and preserved at room temperature $\left({ }^{\circ} \mathrm{C}\right)$ for future use.

The fungi were isolated from the collected samples following the 'Tissue planting method' on Potato Dextrose Agar (PDA) medium (CAB 1968), Blotter method and Paper towel method (ISTA 1996). For the Tissue planting method, 300 seeds were washed in sterile water and then surface sterilized by $10 \%$ Chlorox. Then, they were transferred to sterilized blotting paper to remove the excess surface water. The seeds were placed in Petri plates containing sterilized PDA medium. The inoculated plates were incubated at $25 \pm 2{ }^{\circ} \mathrm{C}$ for 5-7 days. The association of the fungi with cotton seeds was recorded thrice by this method within two months of harvest, after 6 and 10 months of storage.

The identification of the isolates was determined based on the morphological characteristics observed under a compound microscope following standard literature (Thom and Rapper 1945, Rapper and Thom 1949, Subramanian 1971, Barnett and Hunter 2000, Benoit and Mathur 1970, Booth 1971, Ellis 1971, 1976, Sutton 1980). Per cent frequency of occurrence of the fungi was calculated by adopting the formula of Spurr and Wetly (1972).

For the determination of germination, 300 seeds of each sample were taken and placed in 30 PDA plates. The plates were then incubated at room temperature $\left({ }^{\circ} \mathrm{C}\right)$ for seven days. Seeds producing both plumule and radical were considered as germinated seeds. Germination was recorded after seven days and expressed as percentage.

The seed quality, seedling mortality and seeding height of different varieties of cotton seeds were determined according to the method described by Shamsi and Khatun (2016). The seedling vigor index of different cotton varieties was recorded with the formula of Lee et al. (2008).

\section{RESULTS AND DISCUSSION}

Twenty four species of fungi belonging to 12 genera were found to be associated with the seeds of 14 varieties (CB 1- CB 14) of cotton. The isolated fungi were Aspergillus flavus Link, A. fumigatus Fresenius, A. niger (Type 1 and Type 2) Van Tiegh, A. ochraceus K. Wilhelm, A. nidulans Eidam, Aspergillus sp.1, Aspergillus sp.2, Aspergillus sp.3, Curvularia lunata (Wakker) Boedijn, Colletotrichum gloeosporioides Penz and Sacc, C. gossypii Southw., Chaetomium globosum Kunze., Fusarium nivale (Fr.) Sorauer, F. moniliforme J. Shelden, F. oxysporum Schlechtendal, F. fujikuroi Nirenberg, Mucor sp. P. Micheli ex L., Penicillium sp.1 and sp.2 Link, Rhizoctonia solani Khun., Rhizopus stolonifer (Ehrenb.) Vuill., Rhizomucor Lucet \& Costantin, Syncephalastrum racemosum Cohn and Trichoderma viride Pers. (Figs. 1 and 2).

The fungi associated with cotton seeds within two months of harvest is presented in Table 1. Nineteen species of fungi belonging to 10 genera were associated with 14 varieties of cotton seeds. The isolated fungi were Aspergillus flavus, A. fumigatus, A. niger (Type 1), A. niger (Type 2), Aspergillus sp.1, 2 and 3, Curvularia lunata, Colletotrichum gossypii, C. gloeosporioides, Chaetomium globosum, Fusarium oxysporum, F. nivale, F. fujikuroi, Mucor sp., Penicillium sp.1 and 2, Rhizopus stolonifer, Rhizoctonia solani and Trichoderma viride. Prevalence of A. niger (Type 1) and Aspergillus sp.3 was highest $(100 \%)$ in cotton variety CB12 and CB9, respectively, whereas prevalence of C. lunata, $C$. gossypii, Mucor sp. and Penicillium sp.2 were lowest (2\%). The total association was the highest in CB12 (269) and the lowest in CB8 (61). 


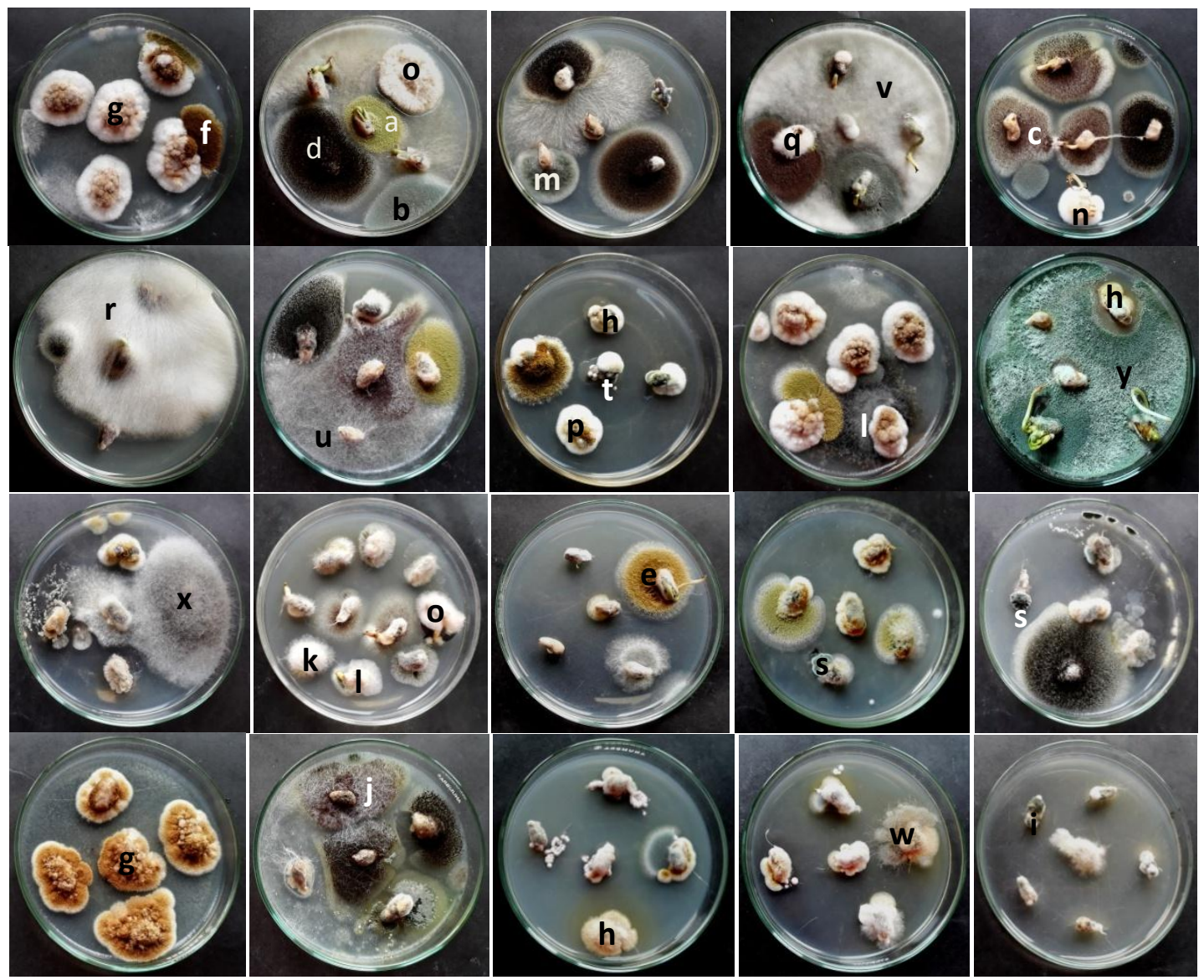

Fig. 1. Fungi associated with the seeds of different cotton varieties (CB1-CB14). a. Aspergillus flavus; b. A. fumigatus; c. A. niger (Type 2); d. A. niger (Type 1); e. Aspergillus sp.1; f. Aspergillus sp.2; g. Aspergillus sp.3; h. A. ochraceus; i. A. nidulans; j. Chaetomium globosum; k. Colletotrichum gossypii; l. C. gloeosporioides; m. Curvularia lunata; n. Fuarium oxysporum; o. F. nivale; p. F. moniliforme; q. F. fujikuroi; r. Mucor sp.; s. Penicillium sp.1; t. Penicillium sp.2; u. Rhizopus stolonifer; v. Rhizoctonia solani; w. Rhizomucor sp.; x. Syncephalastrum racemosum; and $\mathbf{y}$. Trichoderma viride.

Table 2 represents the association of fungi with cotton seeds after six months of storage. The associated fungi were Aspergillus flavus, A. fumigatus, A. niger (Type 1 and 2), Aspergillus sp.1, 2 and 3, A. ochraceus, Chaetomium globosum, Fusarium nivale, F. moniliforme, Penicillium sp.1, Mucor sp., Rhizopus stolonifer, Rhizoctonia solani and Syncephalastrum racemosum. The frequency percentage of $R$. stolonifer was the highest (100\%) in CB5 and CB10. On the other hand, the lowest (2\%) was found in Aspergillus sp.1, A. ochraceus, Penicillium sp.1, Chaetomium globosum and Syncephalastrum racemosum. The total association was the highest in CB10 (208) and the lowest in CB8 (50).

The prevalence of fungi with the seeds of cotton after 10 months is presented in Table 3 . The isolated fungi were Aspergillus flavus, A. fumigatus, Aspergillus niger (Type 1), A. nidulans, A. ochraceus, Aspergillus sp.2, A. sp.3, Curvularia lunata, Chaetomium globosum, Fusarium nivale, Mucor sp., Penicillium sp.1, Rhizopus stolonifer, Rhizoctonia solani, Rhizomucor sp. and Trichoderma viride. The frequency percentage of Aspergillus spp., Chaetomium globosum, Rhizopus stolonifer and Penicillium sp.1 gradually increased with the increase of storage period. The prevalence of Aspergillus sp.3 was the highest (100\%) in CB10. Aspergillus sp. 2, A. ochraceus, Curvularia lunata and 
Trichoderma viride was recorded the lowest (2\%) in $\mathrm{CB} 1, \mathrm{CB} 12$ and $\mathrm{CB} 6$, respectively. The total association was the highest in CB10 (177) and the lowest in CB2 (53).

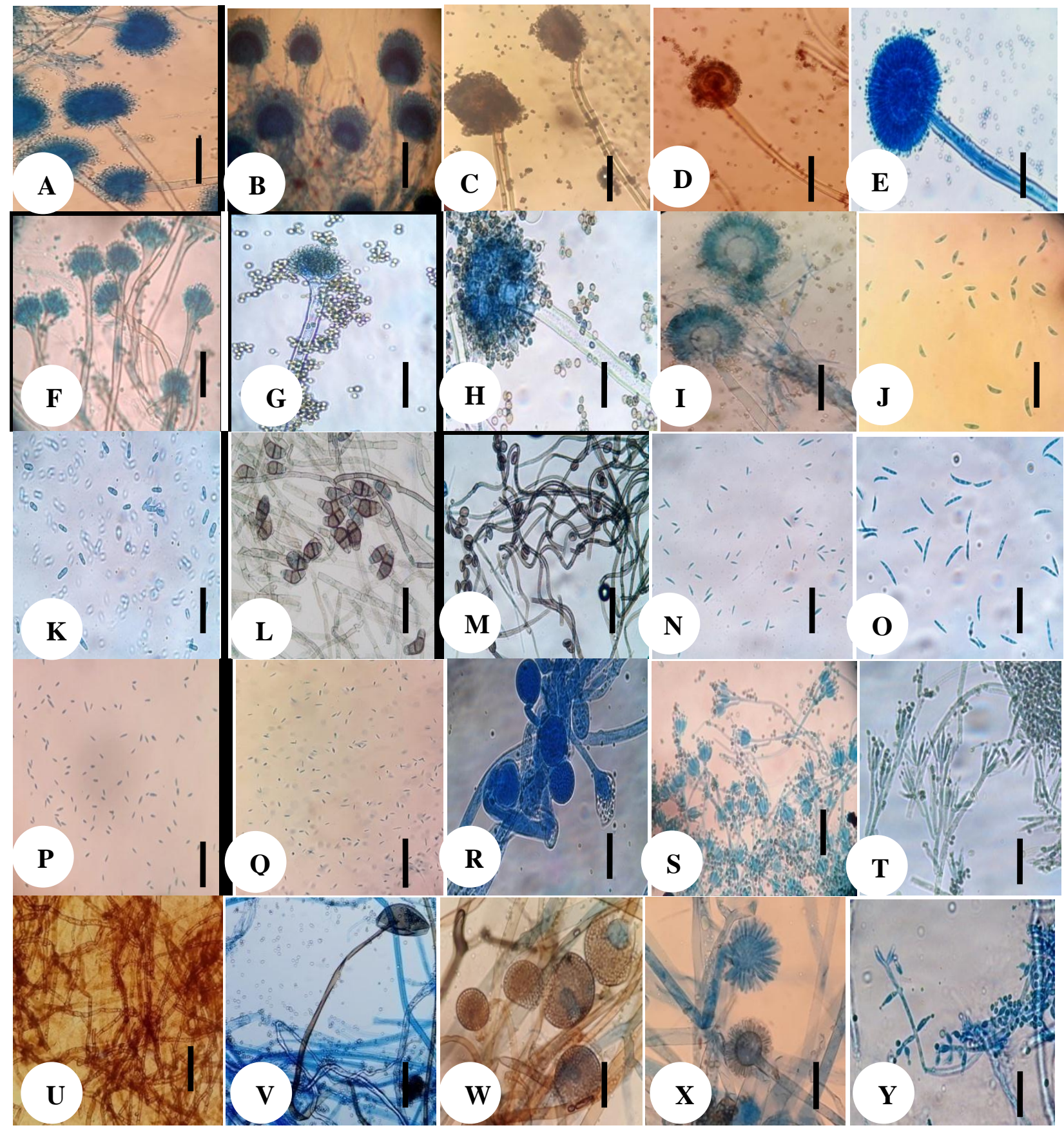

Fig. 2. Conidia, conidiophores and hyphae of different fungi associated with cotton seeds. A. Aspergillus flavus; B. A. fumigatus; C. A. niger (Type 1); D. A. niger (Type 2); E. A. ochraceus; F. A. nidulans; G. Aspergillus sp.1; H. Aspergillus sp.2; I. Aspergillus sp.3; J. Colletotrichum gossypii; K. C. gloeosporioides; L. Curvularia lunata; M. Chaetomium globosum; N. Fusarium oxysporum; O. F. nivale; P. F. moniliforme; Q. F. fujikuroi; R. Mucor sp.; S. Penicillium sp.1; T. Penicillium sp.2; U. Rhizoctonia solani; V. Rhizopus stolonifer; W. Rhizomucor sp.; X. Syncephalastrum racemosum; and Y. Trichoderma viride $(\mathrm{Bar}=50 \mu \mathrm{m})$. 
Table 1. Percentage of association of fungi with different varieties of cotton seeds within two months of harvest.

\begin{tabular}{|c|c|c|c|c|c|c|c|c|c|c|c|c|c|c|}
\hline \multirow[t]{2}{*}{ Name of fungi } & \multicolumn{14}{|c|}{ Frequency percentage of fungi with different varieties of cotton seeds } \\
\hline & CB 1 & CB 2 & CB 3 & CB 4 & CB 5 & CB 6 & CB 7 & CB 8 & CB 9 & CB 10 & CB 11 & CB 12 & CB13 & CB14 \\
\hline Aspergillus flavus & 4 & - & 12 & 16 & - & 36 & 8 & 3 & - & 12 & 4 & 23 & 3 & 3 \\
\hline Aspergillus fumigatus & 12 & 26 & 6 & 10 & 18 & - & - & 18 & - & 16 & 3 & 10 & - & - \\
\hline Aspergillus niger ( $\mathrm{T}_{1}$ ) & 28 & 10 & 16 & 8 & 16 & 4 & 34 & 4 & 6 & 8 & 34 & 100 & 52 & 96 \\
\hline Aspergillus niger ( $\mathrm{T}$ 2) & - & - & - & - & 10 & - & - & 4 & - & - & 20 & 48 & 50 & 24 \\
\hline Aspergillus sp. 1 & 8 & - & 4 & - & 6 & - & - & - & - & - & - & - & - & - \\
\hline Aspergillus sp. 2 & - & - & - & - & - & - & 86 & - & - & 4 & - & - & - & - \\
\hline Aspergillus sp. 3 & - & - & - & 34 & - & - & 44 & - & 100 & 86 & - & - & - & - \\
\hline Chaetomium globosum & - & - & - & - & - & - & - & - & - & 20 & - & - & - & - \\
\hline $\begin{array}{l}\text { Colletotrichum } \\
\text { gloeosporioides }\end{array}$ & - & 7 & 9 & - & - & - & 7 & 3 & 5 & - & - & - & - & 3 \\
\hline $\begin{array}{l}\text { Colletotrichum } \\
\text { gossypii }\end{array}$ & - & - & - & 2 & - & - & - & - & - & - & - & - & - & - \\
\hline Curvularia lunata & - & - & - & 2 & 3 & - & - & - & - & - & 2 & 2 & - & 6 \\
\hline Fusarium fujikuroi & 8 & - & - & - & - & - & - & 6 & - & - & - & - & 4 & - \\
\hline Fusarium oxysporum & - & - & - & - & - & - & - & - & - & - & - & 6 & - & - \\
\hline Fusarium. nivale & - & 14 & 4 & 5 & - & 7 & - & 8 & - & 6 & 3 & - & 3 & 3 \\
\hline Mucor sp. & - & - & - & - & - & - & - & - & - & 2 & - & 8 & 4 & 8 \\
\hline Penicillium sp. 1 & 8 & - & 4 & - & 10 & - & - & - & - & 14 & 3 & - & - & - \\
\hline Penicillium sp. 2 & - & 4 & - & - & - & - & - & 4 & - & - & - & - & 2 & 8 \\
\hline Rhizoctonia solani & 8 & 6 & - & - & 5 & - & - & - & - & - & - & 52 & 10 & 8 \\
\hline Rhizopus stolonifer & 30 & 30 & 50 & - & 8 & 10 & 22 & 8 & 20 & 12 & 35 & 20 & - & 4 \\
\hline Trichoderma viride & - & 4 & 4 & 24 & 12 & 12 & 10 & 4 & 6 & - & - & - & 3 & - \\
\hline Total fungi & 106 & 101 & 109 & 98 & 88 & 69 & 211 & 61 & 137 & 180 & 102 & 269 & 131 & 162 \\
\hline
\end{tabular}

Table 2. Frequency percentage of association of fungi with different varieties of cotton seeds after six months of storage.

\begin{tabular}{|c|c|c|c|c|c|c|c|c|c|c|c|c|c|c|}
\hline \multirow[t]{2}{*}{ Name of fungi } & \multicolumn{14}{|c|}{ Frequency percentage of fungi with different varieties of cotton seeds } \\
\hline & CB1 & CB2 & CB3 & CB4 & CB5 & CB6 & CB7 & CB8 & CB9 & CB10 & CB11 & CB12 & CB13 & CB14 \\
\hline Aspergillus flavus & 6 & 12 & 6 & 16 & 20 & 10 & 20 & 6 & 12 & 24 & 12 & 12 & 24 & 48 \\
\hline Aspergillus fumigatus & 3 & 10 & - & - & 14 & 8 & - & 8 & 4 & 6 & 3 & 22 & 10 & 28 \\
\hline Aspergillus niger ( $\mathrm{T}_{1}$ ) & 4 & 22 & 16 & 10 & 30 & 6 & 14 & 12 & 4 & 36 & 60 & 20 & 84 & 10 \\
\hline Aspergillus niger ( $\mathrm{T}$ 2) & - & - & - & - & - & - & - & - & - & - & 33 & 14 & 16 & 6 \\
\hline Aspergillus ochraceus & 12 & - & - & 2 & - & - & - & 4 & - & - & - & - & - & - \\
\hline Aspergillus sp. 1 & - & 4 & - & - & 2 & - & - & - & - & 28 & - & 4 & - & 3 \\
\hline Aspergillus sp. 2 & 14 & - & - & - & - & - & - & - & - & 14 & - & - & 10 & 4 \\
\hline Aspergillus sp. 3 & 60 & - & 46 & 34 & - & 56 & 34 & 6 & 36 & - & - & - & - & - \\
\hline Chaetomium globosum & - & 2 & - & - & - & - & - & - & - & - & 3 & 12 & - & - \\
\hline Fusarium moniliforme & 4 & - & - & - & 3 & - & - & - & - & - & 5 & - & - & - \\
\hline Fusarium nivale & - & 4 & - & 5 & - & - & - & - & - & - & - & - & - & 6 \\
\hline Mucor sp. & - & - & 3 & - & - & - & 3 & 4 & - & - & - & 4 & - & - \\
\hline Penicillium sp. 1 & 10 & 8 & - & 6 & 4 & 6 & - & 10 & - & - & 2 & 2 & - & 3 \\
\hline Rhizoctonia solani & - & - & - & - & - & - & - & - & - & - & 10 & - & - & - \\
\hline Rhizopus stolonifer & 10 & 70 & 62 & 52 & 100 & 40 & 4 & - & 52 & 100 & 20 & 12 & 10 & 10 \\
\hline $\begin{array}{l}\text { Syncephalastrum } \\
\text { racemosum }\end{array}$ & 2 & - & - & - & - & - & - & - & - & - & - & - & - & - \\
\hline Total fungi & 124 & 132 & 133 & 125 & 173 & 126 & 75 & 50 & 108 & 208 & 148 & 102 & 154 & 117 \\
\hline
\end{tabular}

The results are in agreement with the findings of Mansoori and Hamdolahzadeh 1995), who isolated Alternaria alternata, Aspergillus niger, Fusarium acuminatum, F. solani, Pythium ultimum, Rhizopus arrhizus and Rhizoctonia solani from cotton seeds. F. oxysporum and F. solani were the 
predominating species which gradually decreased with the increase of storage fungi like the species of Aspergillus, Penicillium and Rhizopus. Aspergillus sp. was the highest.

Table 3. Percentage of the association of fungi with different varieties of cotton seeds after ten months of storage.

\begin{tabular}{|c|c|c|c|c|c|c|c|c|c|c|c|c|c|c|}
\hline \multirow[t]{2}{*}{ Name of fungi } & \multicolumn{14}{|c|}{ Frequency percentage of fungi with different varieties of cotton seeds } \\
\hline & CB1 & CB2 & CB3 & CB4 & CB5 & CB6 & CB7 & CB8 & CB 9 & CB10 & CB11 & CB12 & CB13 & CB14 \\
\hline Aspergillus flavus & 2 & 7 & 24 & 9 & 12 & - & 4 & 25 & 10 & 3 & 8 & 12 & 17 & 24 \\
\hline Aspergillus nidulans & 4 & - & - & 6 & - & - & - & - & - & - & - & - & - & - \\
\hline Aspergillus sp. 2 & 2 & - & 14 & 10 & 10 & 22 & 17 & 4 & 18 & 4 & - & 5 & 3 & 4 \\
\hline Aspergillus fumigatus & 6 & 4 & 8 & 8 & 4 & 10 & 12 & 9 & 8 & 12 & 4 & 4 & 7 & 6 \\
\hline Aspergillus niger ( $\mathrm{T}_{1}$ ) & - & 7 & 16 & - & 30 & 24 & 9 & 6 & 10 & 16 & 70 & 24 & 78 & 34 \\
\hline Aspergillus ochraceus & - & - & - & - & 3 & - & 4 & - & 19 & - & - & 2 & - & 4 \\
\hline Aspergillus sp. 3 & 6 & - & 38 & 46 & - & - & 96 & - & - & 100 & - & - & - & - \\
\hline Chaetomium globosum & 18 & 25 & 16 & 22 & 5 & 28 & 7 & 4 & 20 & - & - & 13 & - & 52 \\
\hline Curvularia lunata & - & - & - & - & - & 2 & - & 3 & - & - & - & - & - & - \\
\hline Fusarium nivale & 10 & - & - & - & 5 & - & - & 6 & - & - & 3 & - & 3 & - \\
\hline Mucor sp. & - & - & - & - & - & - & - & - & 3 & - & - & - & - & - \\
\hline Penicillium sp. 1 & 30 & - & 4 & 14 & 10 & 10 & 14 & 25 & 4 & 32 & - & 36 & 15 & 38 \\
\hline Rhizoctonia solani & - & - & - & - & - & - & 10 & - & - & - & - & - & - & - \\
\hline Rhizoтисоr sp. & - & - & - & - & - & - & - & - & 3 & - & - & - & - & - \\
\hline Rhizopus stolonifer & - & 10 & - & 11 & 12 & - & - & - & 45 & 10 & 100 & 21 & 20 & 10 \\
\hline Trichoderma viride & - & - & - & - & - & - & - & 4 & & - & - & - & - & 2 \\
\hline Total fungi & 83 & 53 & 120 & 126 & 117 & 116 & 173 & 96 & 139 & 177 & 185 & 119 & 148 & 174 \\
\hline
\end{tabular}

Table 4 shows that twenty four species of fungi were found to be associated with fourteen varieties of cotton seeds. Aspergillus flavus, A. fumigatus, A. niger, Chaetomium globosum, Penicillium sp.1 and Rhizopus stolonifer were found in all varieties examined and frequency percentage of the association of these fungi were also higher. These were the most predominant fungi in terms of prevalence. These six predominant fungi varied in prevalence with respect to variety and time duration, whereas Colletotrichum gossypii, Fusarium oxysporum, Syncephalastrum racemosum and Rhizomucor sp. were exclusively isolated from only one variety. The frequency percentages of these fungi were very low. The total association of fungi in cotton seeds was the highest in CB10 (204) and the lowest in CB8 (71). On the other hand, the total association of Rhizopus stolonifer was the highest (337) and Colletotrichum gossypii was the lowest (1). Alternaria tenuis, Aspergillus flavus, A. niger, A. fumigatus, Fusarium moniliforme and Rhizopus nigricans were also reported predominant in the cotton seeds of Bangladesh by Lutfunnessa and Shamsi (2011).

The quality percentage and humidity of different varieties of cotton seeds are presented in Table 5 . The study revealed that, in respect of purity, all the cotton varieties individually did not follow the standard of CDB (Anon. 2016-2017), but the mean value followed the standard. In respect of other seeds and non seeds, they have followed the standard. The maximum purity percentage was 99.92 in CB13 and the minimum was 97.08 in CB12. On the other hand, the maximum other seed percentage was 0.91 in CB12 and minimum was 0.0\%. The maximum non or abio seed percentage was 1.0 in CB5 and minimum percentage was 0.10 in $\mathrm{CB} 13$. Maximum humidity percentage was 11.3 in $\mathrm{CB} 12$ and minimum in CB5 (10). All these factors followed the standard of CDB rules (Anon. 2016-2017).

Table 6 shows the germination, seedling mortality, seedling height and vigor index of 14 varieties of cotton seeds. The germination percentage of seeds was the highest in CB 10 (93) and the lowest in CB4 (80). The percentage of seedling mortality was the highest in CB11 (50.30) and the lowest in CB7 
(16.05). The length of shoot was the highest in CB $2(19.8 \mathrm{~mm})$ and the lowest in CB $4(9.0 \mathrm{~mm})$ whereas root length was the highest in CB $5(4.6 \mathrm{~mm})$ and the lowest in CB $9(3.0 \mathrm{~mm})$. The vigor index was the highest in CB10 (2064.6) and the lowest in CB4 (952.0).

Table 4. Average per cent incidence of fungi with 14 varieties of cotton seeds after 10 months of storage.

\begin{tabular}{|c|c|c|c|c|c|c|c|c|c|c|c|c|c|c|c|}
\hline \multirow{2}{*}{ Name of fungi } & \multicolumn{14}{|c|}{ Frequency percentage of fungi with different varieties of cotton seeds } & \multirow{2}{*}{$\begin{array}{l}\text { Total } \\
\text { fungi }\end{array}$} \\
\hline & CB 1 & CB2 & CB 3 & CB4 & CB 5 & CB6 & CB7 & CB8 & CB9 & CB10 & CB11 & CB12 & CB13 & CB14 & \\
\hline Aspergillus flavus & 4 & 6 & 14 & 14 & 11 & 16 & 20 & 12 & 7 & 13 & 8 & 16 & 15 & 25 & 181 \\
\hline A. fumigatus & 7 & 14 & 5 & 6 & 12 & 6 & 4 & 12 & 6 & 11 & 6 & 12 & 6 & 12 & 119 \\
\hline A. nidulans & 2 & - & - & 3 & - & - & - & - & - & - & - & - & - & - & 5 \\
\hline A. niger ( $\mathrm{T} 1)$ & 11 & 13 & 16 & 6 & 25 & 12 & 19 & 8 & 7 & 20 & 55 & 48 & 72 & 47 & 359 \\
\hline A. niger (T 2) & - & - & - & - & 4 & - & - & 2 & - & - & 18 & 21 & 22 & 10 & 77 \\
\hline A. ochraceus & 4 & - & - & 2 & 1 & - & 2 & 2 & 6 & - & - & 2 & - & 2 & 21 \\
\hline Aspergillus sp. 1 & 3 & 2 & 2 & - & 3 & - & - & - & - & 10 & - & 2 & - & 1 & 23 \\
\hline Aspergillus sp. 2 & 5 & - & 5 & 3 & 3 & 7 & 6 & 2 & 6 & 9 & - & 5 & 5 & 3 & 53 \\
\hline Aspergillus sp. 3 & 22 & - & 28 & 38 & - & 19 & 58 & 2 & 45 & 74 & - & - & - & - & 286 \\
\hline Chaetomium globosum & 6 & 9 & 6 & 8 & 2 & 9 & 3 & 2 & 7 & 7 & 2 & 8 & 2 & 18 & 89 \\
\hline $\begin{array}{l}\text { Colletotrichum } \\
\text { gloeosporioides }\end{array}$ & - & 3 & 3 & - & - & - & 2 & 1 & 2 & - & - & - & - & 1 & 12 \\
\hline C. gossypii & - & - & - & 1 & - & - & - & - & - & - & - & - & - & - & 1 \\
\hline Curvularia lunata & - & - & - & 1 & 1 & 1 & - & 1 & - & - & 1 & 2 & - & 2 & 9 \\
\hline Fusarium fujikuroi & 3 & - & - & - & - & - & - & 2 & - & - & - & - & 2 & - & 7 \\
\hline F. moniliforme & 2 & - & - & - & 3 & - & - & - & - & - & 3 & - & - & - & 8 \\
\hline$F$. nivale & 3 & 6 & 2 & 3 & 2 & 3 & - & 5 & 2 & 2 & 3 & - & 2 & 3 & 36 \\
\hline F. oxysporum & - & - & - & - & - & - & - & - & - & - & - & 4 & - & - & 4 \\
\hline Mucor sp. & - & - & 1 & - & - & - & - & 2 & 2 & 2 & - & 4 & 2 & 3 & 16 \\
\hline Penicillium sp. 1 & 18 & 3 & 2 & 7 & 5 & 6 & 5 & 12 & 2 & 16 & 2 & 13 & 5 & 14 & 110 \\
\hline Penicillium sp. 2 & - & 2 & - & - & - & - & - & 2 & - & - & - & - & 2 & 3 & 9 \\
\hline Rhizoctonia solani & 3 & 2 & - & - & 2 & - & 3 & - & - & - & 5 & 17 & 4 & 3 & 39 \\
\hline Rhizomисоr sp. & - & - & - & - & - & - & - & - & 2 & - & - & - & - & - & 2 \\
\hline Rhizopus stolonifer & 14 & 37 & 38 & 21 & 40 & 17 & 9 & 3 & 39 & 41 & 52 & 18 & 3 & 5 & 337 \\
\hline $\begin{array}{l}\text { Syncephalastrum } \\
\text { racemosum }\end{array}$ & 2 & - & - & - & - & - & - & - & - & - & - & - & - & - & 2 \\
\hline Trichoderma viride & - & 2 & 2 & 8 & 4 & 4 & 3 & 3 & 2 & - & - & - & 1 & 1 & 31 \\
\hline Total fungi & 109 & 99 & 124 & 125 & 118 & 101 & 128 & 71 & 133 & 204 & 155 & 172 & 143 & 153 & \\
\hline
\end{tabular}

Storage fungi deteriorate the quality and quantity of seeds in storage. The fungal population of 14 varieties of cotton seeds was extensively studied up to 10 months of storage. The occurrence and abundance of fungi were different with duration of storage period. The association of A. nidulans, Colletotrichum gossypii, Fusarium nivale, Rhizomucor sp., and Syncephalastrum racemosum with cotton seeds is new addition to the field of Mycology and Plant Pathology in Bangladesh. These findings clearly exhibited the diversity of the fungi on different varieties of cotton seeds. 
Table 5. Percentage of pure seeds, other seeds, abio seeds and humidity of different varieties of cotton seeds.

\begin{tabular}{ccccc}
\hline $\begin{array}{c}\text { Name of Cotton } \\
\text { Varieties }\end{array}$ & $\begin{array}{c}\text { Pure seed } \\
(\boldsymbol{\%})\end{array}$ & $\begin{array}{c}\text { Other seed } \\
(\boldsymbol{\%})\end{array}$ & $\begin{array}{c}\text { Abio or non } \\
\text { seed }(\boldsymbol{\%})\end{array}$ & $\begin{array}{c}\text { Humidity } \\
(\boldsymbol{\%})\end{array}$ \\
\hline CB1 & 99.55 & 0.0 & 0.79 & 10.9 \\
CB2 & 98.78 & 0.03 & 0.61 & 10.6 \\
CB3 & 99.0 & 0.0 & 0.54 & 11.2 \\
CB4 & 98.45 & 0.0 & 0.95 & 10.5 \\
CB5 & 99.91 & 0.0 & 1.0 & 10.0 \\
CB6 & 97.47 & 0.0 & 0.56 & 10.7 \\
CB7 & 98.77 & 0.0 & 0.40 & 10.7 \\
CB8 & 98.41 & 0.1 & 0.82 & 10.4 \\
CB9 & 98.39 & 0.0 & 0.89 & 10.8 \\
CB10 & 99.80 & 0.0 & 0.90 & 10.6 \\
CB11 & 97.91 & 0.0 & 0.49 & 10.7 \\
CB12 & 97.08 & 0.91 & 0.91 & 11.3 \\
CB13 & 99.92 & 0.10 & 0.10 & 11.2 \\
CB14 & 98.19 & 0.49 & 0.49 & 11.2 \\
\hline Mean & 98.69 & 0.12 & 0.67 & 10.78 \\
\hline
\end{tabular}

Cotton for its extra quality fiber secures an important position amongst the fiber crops. But, the seeds of cotton in the storage condition become more susceptible to fungal infection resulting in the lowering seed germination and deterioration in storage.

Table 6. Effects of seed borne fungi on germination, seedling mortality, seedling height and vigor of cotton seeds.

\begin{tabular}{|c|c|c|c|c|c|}
\hline \multirow{2}{*}{$\begin{array}{l}\text { Name of } \\
\text { varieties }\end{array}$} & \multirow{2}{*}{$\begin{array}{c}\text { \% Germination } \\
\left(5^{\text {th }} \text { day }\right)\end{array}$} & \multirow{2}{*}{$\begin{array}{c}\text { \% Mortality } \\
\left(7^{\text {th }} \text { day }\right)\end{array}$} & \multicolumn{2}{|c|}{ Seedling height $\left(5^{\text {th }}\right.$ day $)$} & \multirow[t]{2}{*}{ Vigor index } \\
\hline & & & Root (mm) & Shoot (mm) & \\
\hline CB 1 & 82 & 25.39 & 4.4 & 15.0 & 1590.8 \\
\hline CB 2 & 83 & 27.71 & 3.1 & 19.8 & 1892.4 \\
\hline CB 3 & 85 & 35.29 & 3.2 & 11.3 & 1232.5 \\
\hline CB 4 & 80 & 31.25 & 2.9 & 9.0 & 952.0 \\
\hline CB 5 & 81 & 33.33 & 4.6 & 16.6 & 17717.2 \\
\hline CB 6 & 87 & 43.93 & 2.3 & 10.3 & 1096.2 \\
\hline CB 7 & 81 & 16.05 & 3.8 & 16.3 & 1628.1 \\
\hline CB 8 & 92 & 23.91 & 3.9 & 13.2 & 1573.2 \\
\hline CB 9 & 81 & 45.89 & 3.0 & 12.9 & 1287.9 \\
\hline CB10 & 93 & 26.88 & 3.7 & 18.5 & 2064.6 \\
\hline CB11 & 92 & 50.30 & 3.8 & 17.4 & 1950.4 \\
\hline $\mathrm{CB} 12$ & 84 & 21.43 & 3.5 & 14.9 & 1545.6 \\
\hline CB13 & 83 & 22.98 & 3.7 & 15.0 & 1552.1 \\
\hline CB14 & 91 & 47.88 & 4.5 & 17.8 & 2029.3 \\
\hline
\end{tabular}

A damage seed will produce an abnormal seedling. The findings suggest that there is a need for proper storage of cotton seeds to minimize the fungal growth. There is also a clear need to increase public awareness on the aspects related to seed health and to develop suitable management practices for improving the quality of the seeds. Present findings will be helpful for designing the management of the mycoflora of cotton in storage.

\section{ACKNOWLEGEMENTS}

The first author gratefully acknowledges to the Ministry of Science and Technology, People's Republic of Bangladesh for providing the financial support in her research through NST fellowship. 


\section{REFERENCES}

Anonymous. 2016-17. The quality of good cotton seeds. The Annual Report and Work plan 2016-2017, Cotton Development Board (CDB), Khamarbari, Farmgate, Dhaka-1215.

Barnett, H. L. and B. B. Hunter. 2000. Illustrated Genera of Imperfect Fungi. Burgess Pub. Co., Minneapolis. 185 pp.

Benoit, M. A. and S. B. Mathur. 1970. Identification of species Curvularia on rice seed. Proc. Inst. Seed Test. Ass. 35(1): 1-23.

Booth, C. 1971. The Genus Fusarium. The Commonwealth Mycological Institute, Kew, Surrey, England. 237 pp.

CAB, 1968. Plant Pathologist's Pocket Book. 1st ed. The Commonwealth Mycological Institute, England. $267 \mathrm{pp}$.

Eisa A., G. M. El-Hubbaa, M. F. Abdoul-Ella and S. R. Hassan. 2007. Associated fungi with seeds of some Egyptian cotton cultivars and their effect on the plant mortality production and oil content. $15 \mathrm{pp}$.

Ellis, M. B. 1971. Dematiaceous Hyphomycetes. The Commonwealth Mycological Institute, England. $608 \mathrm{pp}$.

Ellis, M. B. 1976. More Dematiaceous Hyphomycetes. The Commonwealth Mycological Institute, England., pp. 326-328.

ISTA, 1996. International Rules of Seed Testing Association. Proc. Int. Seed Test. Assoc., pp. 19-41.

Jeyalakshmi, C., Doraisamy, Sabitha and V. Valluvaparidasan. 1999. Studies on the seed borne mycoflora of MCU cotton cultivars, their effect and biological control. J. Cotton Res. Dev. 13: 35-39.

Khanzada, K. A., M. A. Rajput, G. S. Shah, A. M. Lodhi and F. Mehboob. 2002. Effect of seed dressing fungicides for the control of seed borne mycoflora of wheat. Asian J. Plant Sci. 1(4): 441-444.

Lee, K. J., S. Kamala-Kannan, H. S. Sub, C. K. Seong and G. W. Lee. 2008. Biological control of Phytophthora blight in red pepper (Capsicum annuum L.) using Bacillus subtilis. World J. Microbiol. Biotechnol. 24: 1139-1145.

Lutfunnessa, R. J. F. and S. Shamsi. 2011. Fungal diseases of cotton plant (Gossypium hirsutum L.) in Bangladesh. Dhaka Univ. J. Biol. Sci. 20(2): 139-146.

Machado, J. C. and C. J. Langerak. 2002. General incubation methods for routine seed health analysis In: Seed-borne fungi: a contribution to routine seed health analysis. International Seed Testing Association, Zurich., pp. 48-59.

Mansoori, B. and A. Hamdolahzadeh. 1995. Seed test and seedling disease of cotton in Gorgon and Gonbad. App. Entomol. Phytopathol. 62: 80-83.

Neergaard, P. 1977. Seed Pathology. Vol. I and II. McMillan Press, London, UK. 1187 pp.

Raper, K. B. and C. Thom. 1949. Manual of the Penicillia, Williams and Wilkins, Baltimore, M. D. USA.

Richardson, M. J. 1990. An annotated list of seed-borne diseases. 4th ed. ISTA, Zurich, Switzerland., $365 \mathrm{pp}$. 
Shamsi, S. and A. Khatun. 2016. Prevalence of fungi in different varieties of chickpea (Cicer arietinum L.) seeds in storage. J. Bangladesh Acad. Sci. 40(1): 37-44.

Spurr, H. W. J. and R. E. Wetly. 1972. Incidence of tobacco leaf microflora in relation to brown spot disease and fungicidal treatment. Phytopathol. 62: 916-920.

Subramanian, C.V. 1971. Hyphomycetes. Indian Council of Agriculture Research, New Delhi, 930 pp.

Sutton, B. C. 1980. The Coelomycetes. Fungi Imperfecti with Pycnidia, Acervuli and Stromata. The Commonwealth Mycological Institute, England. 696 pp.

Tripathi, K.K., O.P. Govilla, R. Warrier and V. Ahuja 2014. Biology of Gossypium spp. (Cotton). Agricultural and Biological Sciences. $1 \mathrm{pp}$.

Thom, C. and K. B. Raper. 1945. A manual of the Aspergilli. Williams and Wilkins, Baltimore, M.D. USA.

Tomar, D. S., P. P. Shastry., M. K. Nayak and P. Sikarwar. 2012. Effect of seed borne mycoflora on cotton seed (JK4) and their control. J. Cotton Restitution of Development. 26(1): 105-108. 